\title{
Pourquoi Biens symboliques / Symbolic Goods?
}

Why Biens symboliques / Symbolic Goods?

¿Por qué Biens symboliques / Symbolic Goods?

Le comité de rédaction

\section{(2) OpenEdition}

\section{Journals}

Édition électronique

URL : http://journals.openedition.org/bssg/80

DOI : $10.4000 /$ bssg.80

ISSN : 2490-9424

Éditeur

Presses universitaires de Vincennes

Référence électronique

Le comité de rédaction, "Pourquoi Biens symboliques / Symbolic Goods? 》, Biens Symboliques /

Symbolic Goods [En ligne], 1 | 2017, mis en ligne le 15 octobre 2017, consulté le 04 mars 2021. URL

http://journals.openedition.org/bssg/80 ; DOI : https://doi.org/10.4000/bssg.80 

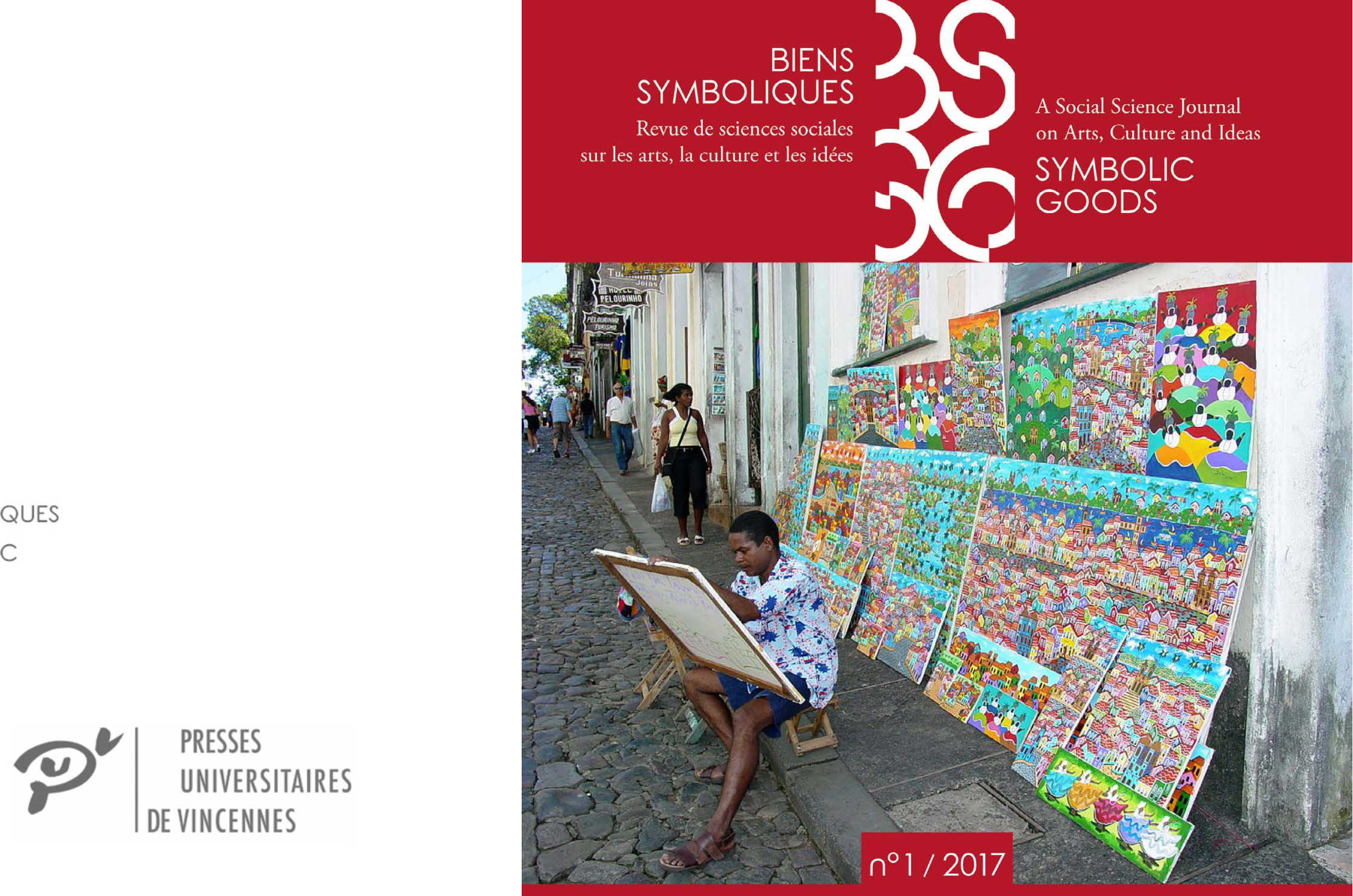

\section{Artistes ordinaires \\ Ordinary Artists}




\title{
Pourquoi Biens symboliques / Why Biens symboliques / Symbolic Goods? Symbolic Goods?
}

\author{
Le comité de rédlaction | The Editorial Board \\ traduction | translation \\ Jean-Yves Bart
}

Issus des studios cinématographiques ou des ateliers d'art, de l'édition ou des revues intellectuelles et savantes, les biens symboliques font l'objet d'un nombre toujours croissant de travaux en sciences sociales. Dans le monde francophone, cependant, il manquait encore à ces derniers un espace d'institutionnalisation, de confrontation et de visibilité internationale permettant à la fois de mesurer les progrès accomplis, et de proposer des croisements originaux ainsi que des directions nouvelles. Telle est la raison d'être de Biens symboliques / Symbolic Goods, revue bilingue de sciences sociales à comité de lecture, ayant une vocation interdisciplinaire et internationale.

Des plus légitimes aux plus ordinaires, les biens symboliques sont produits, échangés et évalués selon des modalités qui échappent en partie aux catégories les plus courantes de l'économie. Cette spécificité justifie la création d'un champ de recherche spécifique en sciences sociales. Mais les biens symboliques participent aussi, plus généralement, de la construction symbolique du monde social. Leur étude, loin de n'être qu'un secteur ou un sous-champ, constitue ainsi un
Whether they come from movie studios or artists' workshops, the publishing industry or academic journals, symbolic goods are the subject of an ever-increasing number of social science studies. And yet this body of work has lacked a space for institutionalization, confrontation, and international exposure in the French-speaking world which would facilitate both measurement of progress made, and the proposal of original ideas of cross-pollination and new avenues of research. This is where our new peer-reviewed, bilingual, interdisciplinary, and international journal, Biens symboliques/Symbolic Goods, comes in.

From the most legitimate to the most ordinary, symbolic goods are produced, exchanged, and assessed in ways that partly elude traditional economic categories - they constitute a specificity that justifies the creation of a distinct field of research in social science. More generally, symbolic goods are also involved in the symbolic construction of the social world. The study of symbolic goods is in this sense far from a mere sub-field; it is a vantage point from which to reconsider 
prisme à travers lequel interroger le fonctionnement passé comme présent de l'ordre social et politique, les fondements

de sa légitimité et les manières dont il peut être contesté.

Biens symboliques / Symbolic Goods promeut donc les sciences sociales des espaces intellectuels et culturels attentives à leur spécialisation et à leur autonomie relative. Loin de se cantonner aux formes artistiques et culturelles les plus reconnues, la revue prend pour objet les biens symboliques au sens large dont font partie les idées politiques, les pratiques amateures, les produits des cultures populaires, les productions numériques, les discours médiatiques et les divers éléments constitutifs des styles de vie (vêtements, habitat, nourriture, etc.). La revue porte attention à la matérialité des biens symboliques ainsi qu'aux logiques qui sous-tendent leurs (re-)qualifications et leur (inégale) diffusion. Elle appréhende l'activité culturelle comme une production collective, mettant aux prises des intérêts multiples, sans limiter l'analyse aux traditionnelles figures de l'« artiste », de l'« auteur.e » ou du « scientifique », mais en s'intéressant également aux personnes et institutions qui concourent, sous une forme ou une autre, à la production des biens symboliques, à leur circulation et à leurs appropriations.

\section{Une perspective interdisciplinaire sur les arts, la culture et les idées}

Biens Symboliques / Symbolic Goods accueille des auteur.e.s des différentes sciences humaines et sociales - sociologie, histoire, anthropologie, science politique, sciences de l'information et de la communication, histoire de l'art, the past and present workings of the social and political orders, the foundations of their legitimacy and the ways in which they can be challenged.

Biens symboliques/Symbolic Goods thus intends to promote social sciences of intellectual and cultural spaces which emphasize their specialization and relative autonomy. Contributions will not be limited to the most recognized artistic and cultural forms; they will also examine symbolic goods in the broader sense, including political ideas, amateur practices, working-class cultural output, digital productions, media discourse, and lifestyle markers (clothing, housing, food, etc.). The journal will pay attention to the materiality of symbolic goods and to the underlying rationales of their (re)definitions and their (unequal) diffusion. It will address cultural activity as a collective production involving multiple interests. This will mean refraining from limiting analysis to the traditional figures of the "artist," "author," or "scholar," and expanding our scope to include all persons and institutions that contribute in some form to the production, circulation, and appropriation of symbolic goods.

\section{An interdisciplinary perspective on arts, culture and ideas}

Biens symboliques/Symbolic Goods will welcome input from a variety of disciplines in human and social science: sociology, history, anthropology, political science, information and communication science, art history, literature, economics, and 
littérature, économie, etc. C'est en effet moins l'appartenance disciplinaire que le point de vue et les démarches auxquels les arts, la littérature, les pratiques culturelles ou les idées sont soumis, qui donnent son unité à la revue. Si la réflexion théorique n'en est pas exclue, la revue revendique son attachement au caractère empirique des travaux proposés aux lecteur.rice's, quels que soient les moyens d'investigation privilégiés (recherche en archives, ethnographie, statistiques, analyse de discours, d'images, etc.).

Une autre caractéristique de Biens symboliques / Symbolic Goods consiste en l'association de trois domaines de recherche : arts, culture, idées. Paradoxalement, les sciences sociales de la culture, entendues comme analyse des pratiques culturelles, des goûts et de la réception par les publics, occupent encore souvent une place anecdotique dans les revues francophones consacrées aux formes d'expression artistiques. Ces deux domaines se voient moins souvent encore associés à l'étude des intellectuels et des idées. Pourtant, les travaux de sciences humaines et sociales qui abordent ces objets reposent bien souvent sur des problématiques analogues, voire communes. L'objectif de Biens symboliques / Symbolic Goods est ainsi de favoriser les approches transversales entre ces domaines autour de questions fondamentales comme celle de la production de la valeur (artistique, intellectuelle, etc.), celle du fonctionnement spécifique de ces sphères d'activité et des formes de domination qui y sont à l'œuvre, ou encore celle de

la production du goût et des idéologies. so on. Emphasis will be placed on consistency of approaches and points of view on the arts, literature, cultural practices, and ideas, rather than on disciplinary affiliations per se. Without excluding theoretical reflection, the journal will seek primarily to give exposure to empirical research, regardless of the methods of investigation used (archival research, ethnography, statistics, discourse analysis, image analysis, etc.).

Another defining feature of Biens symboliques/Symbolic Goods is the association between three areas of research: the arts, culture, and ideas. Paradoxically, the social science of culture, conceived as analysis of cultural practices, tastes, and audience reception, still holds an often-insignificant place in French-language journals dedicated to artistic expression. The two fields are even less often associated with the study of intellectuals and ideas. Yet, studies on these subjects in human and social science are often based on similar, if not shared premises. The objective of Biens symboliques / Symbolic Goods is thus to promote crossdisciplinary approaches in these fields regarding fundamental questions such as the production of (artistic, intellectual, etc.) value, the distinct workings of these spheres of activity, and the forms of domination at work in them, or the production of taste and ideologies. 


\section{Accès ouvert et circulation internationale des travaux}

Biens symboliques / Symbolic Goods est une revue semestrielle exclusivement numérique, offrant à ses lecteur.rice's un accès totalement ouvert à l'ensemble de ses articles. Ce choix s'inscrit dans la perspective d'une libre circulation de travaux de recherche, réalisés pour l'essentiel sur fonds publics, là où les « bouquets » d'abonnements vendus aux universités et aux instituts de recherche réduisent le lectorat à celles et ceux qui y étudient ou y travaillent, et où les « barrières mobiles » laissent trop longtemps refroidir des travaux qui méritent dès leur parution d'être divulgués et discutés. Le carnet de recherches Hypothèses en ligne [https:// bssg.hypotheses.org/] qui accompagne la revue a pour fin d'enrichir cette circulation en proposant des prépublications ou des informations complémentaires aux articles publiés dans les numéros, et d'organiser le contact entre les comités (de rédaction et scientifique), les auteur·e.s et les lecteur.trice.s. La revue ne s'adresse en effet pas seulement aux universitaires, mais aussi aux professionnel.le's de la culture, aux enseignant.e.s, aux artistes, et à toutes les personnes intéressées par les thèmes qu'elle aborde.

Les sciences sociales francophones des biens symboliques souffrent également d'une relative invisibilité sur le plan international en raison notamment de la domination de l'anglais. Publier uniquement en français limiterait drastiquement l'étendue des échanges auxquels la revue entend prendre part. Publier en anglais seulement reviendrait à contourner paresseusement la question du poids de la

\section{Open access and international circulation of research}

Biens symboliques / Symbolic Goods is a digital-only halfyearly journal, offering readers open access to all papers. This choice supports the free circulation of research that is for the most part publicly funded at a time when subscription packages sold to universities and research institutes are reducing readership to those who study and work within them, while "embargoes" slow down access to studies that deserve to be publicized and discussed sooner. Our blog, published on the Hypotheses platform [https://bssg.hypotheses.org/] alongside the journal, will be used to enhance this circulation, by offering pre-publications and complementary material to the papers published in our issues, and to put our editorial and scientific boards, authors, and our readers in touch with each other. Our target audience is not only made up of academics: we hope the journal will be relevant to professionals in the cultural sector, teachers, artists, and any other interested persons.

French-language social science research on symbolic goods also tends to suffer from a lack of international exposure, in part due to the domination of English. Publishing solely in French would mean drastically limiting the scope of the exchanges in which we wish to take part; publishing in English would mean lazily circumventing the question of the influence of linguistic domination on the formation of 
langue sur la formation des concepts, à entériner sans résistance l'hypercentralité de l'anglais et à exclure de son lectorat celles et ceux qui ne maîtrisent pas suffisamment cette langue. Biens symboliques / Symbolic Goods fait par conséquent le choix de publier, dans les dossiers thématiques ou en varia, des articles en français avec leur traduction en anglais (ou inversement). Publier tous les textes de la revue dans plusieurs langues (français, anglais mais aussi espagnol, pour favoriser une circulation réellement internationale des travaux) reste néanmoins notre objectif. La revue porte, en outre, une attention particulière aux recherches menées en dehors des aires anglophones et francophones.

\section{Structure de la revue et contenu du premier numéro}

Que ce soit en varia ou dans les dossiers thématiques, les articles font l'objet de deux expertises en double aveugle. Dans ce premier numéro, Géraldine Bois et Marc Perrenoud proposent un dossierintitulé «Artistes ordinaires» qui aborde la situation des artistes évoluant sur les degrés inférieurs de la pyramide professionnelle, ni riches ni célèbres, produisant des biens symboliques déclassés et dont la carrière se construit souvent à distance des figures légitimes de la

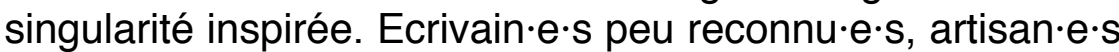
de la musique, comédien-ne·s sans grand succès, ceux et celles qui « font le métier » sans accéder à la consécration représentent une part largement majoritaire dans les espaces du travail artistique. concepts, and simply signing off on the rule of English without resistance, as well as excluding those among our readership who do not have a good command of the language. At Biens symboliques / Symbolic Goods, we have decided to publish articles in French and in their English translations (or the other way around), both in the thematic dossiers and in varia issues. However, publishing full versions of all our papers in several languages (French and English, but also Spanish, to encourage a genuinely international circulation of research and avoid the hegemony of English) remains our goal. The journal will also devote particular attention to research conducted outside of English- and French-speaking areas.

\section{Structure of the journal and content of our first issue}

Both in the varia issues and in the thematic dossiers, papers are subjected to two double-blind peer reviews. For this first issue, Géraldine Bois and Marc Perrenoud have put together a dossier entitled "Ordinary Artists," which examines the situation of artists on the lower rungs of the professional pyramid. Ordinary Artists are neither rich nor famous; they produce symbolic goods that are attributed little value, and their careers are often built far removed from what are considered to be legitimate figures of inspired exceptionalism. Be they little-known writers, studio musicians, or actors working under the radar, those who "do the job" without achieving the recognition they desire make up the vast majority of individuals active in the spaces of artistic labour. 
Outre le dossier qui donne son thème à chaque numéro, la revue propose plusieurs rubriques originales, qui, chacune, paraîtront dans un numéro sur deux.

La rubrique « $(\mathbf{R e})$ lire » présente, d'une part, des comptes rendus croisés d'ouvrages récemment publiés sur un même thème, l'objectif étant de promouvoir la discussion entre les disciplines et la confrontation scientifique des travaux issus de (ou portant sur) différents pays. Elle accueille, d'autre part, des réflexions autour de l'histoire et de la réception d'ouvrages majeurs dans nos disciplines et champs de recherche. II peut également s'agir de donner la parole à des chercheur.se.s dont les travaux ont marqué l'étude de la production ou de la réception des biens symboliques, pour leur permettre de revenir sur leur parcours en interrogeant notamment, dans l'esprit de la revue, les filiations intellectuelles, les conditions de possibilité et modalités concrètes de production de leurs travaux. Dans le présent numéro, cette rubrique accueille une relecture à plusieurs voix du livre Le Savant et le Populaire de Claude Grignon et Jean-Claude Passeron, ouvrage important pour les sciences sociales françaises, mais qui a peu circulé en dehors des frontières nationales. " $(\mathrm{Re})$ lire » propose de recontextualiser la production et la réception de ce livre, et en présente des lectures et appropriations possibles, à partir des contributions d'une dizaine de chercheur·e·s de différentes générations et de plusieurs disciplines.

Produire une revue bilingue comme Biens symboliques / Symbolic Goods soulève une série de questions, rarement abordées publiquement, sur la traduction en sciences humaines et sociales. C'est pourquoi, dans la rubrique
In addition to these dossiers built around a single theme, the journal will also maintain several original sections.

Our "Library" section will include reviews which crossreference books recently published on the same theme to promote discussion across disciplines and the scientific confrontation of research from (or on) various countries. It will also offer contributions on the history and reception of major books in our disciplines and research areas. In some cases, this will mean providing a space for researchers whose work has been crucial to the study of the production or reception of symbolic goods, and reassessing their trajectories to allow them to examine their intellectual filiations, the conditions of possibility, and the practical circumstances involved in the production of their body of work. In this issue, a dozen scholars from different generations and disciplines discuss Claude Grignon and Jean-Claude Passeron's book Le Savant et le Populaire, recontextualizing the book's production and reception, and presenting possible readings and appropriations of a milestone in French social science that has had little exposure abroad.

Producing a bilingual journal raises a number of issues regarding translation in the humanities and social science that are rarely put on the table. In our "Research in translation" section, translators, as well as cultural professionals, teachers, 
«Traduire », des traducteur.rice $\cdot s$ ou des professionnel-le·s de la culture, de l'enseignement ou de la recherche, habituéee-s à travailler entre (et avec) plusieurs langues, seront invité·e.s à expliciter leurs choix et leurs manières de faire, et à soumettre leur travail à une analyse réflexive. Cette rubrique nourrit ainsi également à sa manière un objet central de la revue : la circulation transnationale des textes et des notions. Dans le présent numéro, Marie-Pierre Pouly revient sur les réflexions et les choix à la fois linguistiques et épistémologiques qui ont ponctué son travail de traduction de la sociologue britannique Beverley Skeggs, elle-même spécialisée dans l'étude des classes populaires et du genre.

Autre espace original de réflexion sur la circulation des sciences humaines et sociales, la rubrique « Transmettre » propose des articles et des documents sur l'enseignement, la diffusion hors du monde académique et la mise en débat public des acquis des sciences sociales de la culture et des idées. En s'attachant en particulier à présenter des récits et des analyses d'expériences pédagogiques, la rubrique vise à contribuer à une didactique adaptée à cet ensemble de travaux et aux dispositions des différents publics que ceux-ci peuvent concerner (étudiant·e.s, " grand public », producteur.rice.s culturels...). Dans le prochain numéro, un article de Marc Perrenoud et Pierre-Emmanuel Sorignet présentera un atelier de recherche sur le travail artistique mené avec les étudiant.e.s du Master de sciences sociales à I'Université de Lausanne et qui a abouti à la création d'un spectacle mêlant musique et danse contemporaine. and researchers who routinely work with several languages will be invited to discuss their methods and choices, and adopt a reflexive outlook on their practice. This section will thus contribute to our broader examination of the transnational circulation of texts and concepts. In the current issue, MariePierre Pouly looks back at the linguistic and epistemological challenges of translating the research of British sociologist Beverley Skeggs, who herself specialized in the study of the working class and gender.

"In the classroom and beyond" will be another original space for reflecting on the circulation of human and social science research, featuring articles and documents on teaching, the dissemination of research beyond the confines of academia, and public debate surrounding findings in culture and ideas through social science. Concerned in particular with presenting reports and analysis on practical pedagogical experiments, this section will strive to help identify didactic approaches that suit this body of work and the dispositions of various potential audiences (students, the wider public, cultural producers, etc.). In the forthcoming issue, an article by Marc Perrenoud and Pierre-Emmanuel Sorignet will present a research workshop on artistic labour conducted with students in the social science master's programme at the University of Lausanne, which resulted in the creation of a dance/music show. 
Biens symboliques / Symbolic Goods ne souhaite pas seulement s'adresser aux professionnel-le.s de la culture (au sens large) : elle leur ouvre également ses pages dans la rubrique « Métiers » qui accueille des articles, des entretiens ou des tables rondes consacrés aux pratiques professionnelles dans le domaine des arts, des sciences ou de la médiation culturelle. Ainsi, dans le numéro 2 , une conservatrice de la Bibliothèque nationale de France expliquera les enjeux et les contraintes de l'archivage du web littéraire.

Enfin, la rubrique « Regards sur... » que l'on inaugurera également dans le prochain numéro, présente deux types d'articles. Pour que la revue soit un véritable carrefour d'échanges internationaux, y seront publiées des études ou des approches en sciences humaines et sociales sur les arts, la culture ou les idées qui ont été développées à l'étranger mais demeurent peu connues en France. Cette rubrique accueille également les premiers résultats de travaux en cours de réalisation, de chercheur.se·s travaillant à la croisée des disciplines.

En se donnant pour objet propre la production, la circulation et la réception des biens symboliques, en proposant certaines rubriques qui n'existent nulle part ailleurs et en se donnant les moyens du bilinguisme pour intervenir dans la circulation internationale des travaux, Biens symboliques / Symbolic Goods occupe une place originale au sein du paysage des revues et s'inscrit dans une démarche susceptible d'ouvrir de nouvelles voies dans les recherches sur les arts, la culture et les idées.
The dialogue that Biens symboliques / Symbolic Goods seeks to foster with artists, intellectuals, and cultural professionals will not be one-sided: our "On the job" section will host articles, interviews, and roundtables on professional practices in the fields of the arts, science, and cultural mediation. In our forthcoming issue, a head librarian at the Bibliothèque nationale de France will discuss issues surrounding the process of archiving internet literature.

Lastly, the "Perspectives" section, which will also be launched in the next issue, will feature two types of article. First, in order to make the journal a genuine crossroads for international exchange, it will include examples of approaches in human and social science on the arts, culture, and ideas that have been developed abroad but are little known in France. Second, the section will present the early findings of ongoing studies by scholars working across several disciplines.

Analysing the production, distribution, and reception of symbolic goods, offering sections that no other journal offers and using bilingual publishing to act on the international circulation of works grants Biens Symboliques / Symbolic Goods a unique position in the scientific journals landscape, enabling the journal to possibly open new research paths on arts, culture, and ideas. 